\title{
Bazı Ekmeklik Buğday Çesitlerinde Farklı Tohum İriliklerinin Tane Verimi, Verim Öğeleri ile Kalite Üzerine Etkisi
}

\author{
*Turhan KAHRAMAN Remzi AVCI \\ Trakya Tarımsal Araştırma Enstitüsü, Edirne \\ *Sorumlu yazar e-posta (Corresponding author; e-mail): turhankahraman@hotmail.com
}

\section{Öz}

Bu araştırma; 2007-2009 yılları arasında Trakya Tarımsal Araştırma Enstitüsü deneme alanında, Tesadüf Bloklarında Bölünmüş Parseller Deneme Desenine göre dört tekrarlamalı olarak yürütülmüştür. Denemede; ana parsel olarak çeşitler (Flamura-85, Gelibolu, Kate A-1 ve Guadalupe), alt parsel olarak 4 farklı tohum irilikleri (2.8 mm üstü, 2.8-2.5 mm arası, 2.5-2.2 mm arası ve 2.2-2.0 mm arası) ele alınmıştır. Araştırma; farklı 1000 tane ağırlıklarına sahip dört ekmeklik buğday çeşidinde 4 farklı tohum iriliğinin tane verimi, verim öğeleri ve bazı kalite değerleri üzerine etkisini belirlemek amacıyla yapılmıştır. Yapılan varyans analiz sonucunda tane verimi, metrekarede başak sayısı, başakta tane sayısı, bin tane ağırlığı ve hektolitre ağırığı yönünden çeşitler arasındaki farklılık istatistiki olarak önemli bulunmuştur. Tohum iriliği, her iki yılda da tane verimi, 1000 tane ağırlığı ve hektolitre ağırlığını etkilerken, metrekarede başak sayısını ve başakta tane sayısını etkilememiştir. Tohum iriliği artıkça çeşitlerin tane verimi artmıştır. En yüksek tane verimi $2.8 \mathrm{~mm}$ üstü tohum iriliğinden alınırken, en düşük tane verimi ise 2.0-2.2 mm arası tohum iriliğinden alınmıştır. 1000 tane ağırlığı yüksek olan çeşitlerde tohum iriliği artıkça tane verimindeki artış oranının daha fazla olduğu saptanmıştır. Araştırma sonucunda; bölgede Gelibolu ve Flamura-85 çeşitlerinde 2.5 mm üstü, Kate A-1 çeşidinde $2.2 \mathrm{~mm}$ üstü ve Guadalupe çeşidinde ise $2.0 \mathrm{~mm}$ elek üstü tohumluklar kullanılmalıdır.

Anahtar Kelimeler: Ekmeklik buğday (T. aestivum L.), tohum iriliği, tane verimi, kalite

\section{Effects of Different Seed Sizes on Grain Yield, Yield Components and Quality of Some Bread Wheat ( $T$. aestivum L.) Varieties}

\begin{abstract}
This study was conducted in the experimental field of Trakya Agricultural Research Institute in a randomized split blocks design with four replications in two years (2007-2008 and 2008-2009 growing seasons). The experiment was set up cultivars (Flamura-85, Gelibolu, Kate A-1 ve Guadalupe) as main plot and four different seed size (above $2.8 \mathrm{~mm}$, among 2.8-2.5 mm, among 2.5-2.2 mm and among 2.2-2.0 mm) as subplot. The objective of the study was to determine the effects of four different seed sizes on grain yield, yield components and quality in bread wheat cultivars which have four different kernel weight. According to the results obtained from analyses, differences between cultivars in terms of grain yield, number of spike per square meter, number of kernel per spike, thousand kernel weight, test weight and protein rate were found statistically significant. While grain yield, thousand kernel weight and test weight were affected by the seed size, number of spike per square meter and number of kernel per spike weren't affected by the seed size in both years. The grain yields of cultivars went up with increasing seed size. While the highest yield was obtained with $2.8 \mathrm{~mm}$ and above seed size, between 2.0-2.2 $\mathrm{mm}$ seed size gave the lowest yield. Increasing seed size in cultivars having high kernel weight caused greater yield increase more than in cultivars with low kernel weight. Based on the results of the study, above $2.5 \mathrm{~mm}$ seed size in Gelibolu and Flamura-85, above $2.2 \mathrm{~mm}$ in Kate A-1 and above $2.0 \mathrm{~mm}$ seed size in Guadalupe cultivars were suggested for Trakya region.
\end{abstract}

Keywords: Wheat (T. aestivum L.) bread, seed size, grain yield, quality component

\section{Giriş}

U" kemiz buğday üretiminde verimin düşük olmasının nedenlerinden biri de kullanılan tohumluk kalitesinin düşük olmasıdır. Birim alandan kaldırılan ürün artışında etkili olan tarımsal mekanizasyon, tarımsal mücadele, ekim nöbeti, gübreleme, sulama v.b. faktörler 
yanında en önemli diğer etken de tohumluktur. Tahıl tarımının en önemli girdisi tohumluk olup, kaliteli bir tohumluk, üretimde \%25-40'a varan oranlarda verim artışı sağlayabilmektedir (Harmanşah ve Tanin 1987). Tarımsal ve ticari açıdan tanenin değerlendirilmesinde göz önünde bulundurulan bin tane ağırlığı; tohumluğun kalitesini belirlemede önemli bir özelliktir. Verim fizyolojisi bakımından tane iriliği, verimi artıran önemli bir unsur olarak kabul edilmektedir.

Tane iriliğinin çıkış oranına etkisi üzerine bazı araştırıcılar büyük tohumların daha hızlı çıkış yaptığını ve çıkış oranının küçük tohumlara göre daha yüksek olduğunu bildirirken (Reis and Everson, 1970; Bulisani and Warner 1980; Chastain and Wysocki 1995; Sönmez 2000), bazı araştırıcılar tane iriliğinin çıkış üzerine etkisinin az olduğunu (Mian and Nafzigier 1992); başka araştırıcılar ise, tane iriliğinin çıkış üzerine etkili olmadığını bildirmişlerdir (Douglas and Wilkins 1992). Çıkış oranı, fide boyu, toprak üstü ve kök kuru madde ağırlıkları değerleri büyük tohumlarda daha yüksek olurken, kardeşlenme ve toprak üstü/kök kuru madde ağırlığı oranı tane iriliğinden etkilenmemektedir (Kara ve Akman 2007)

Farklı irilikteki tohumların tane verimleri farklılık gösterirken, kullanılan çeşidin genetik özelliği yanında tane iriliğinin de birim alan tane veriminde olumlu etkisi bulunmaktadır (Ünver 1995). İri tohum, bitkinin ilk gelişme devresini hızlandırırken, bitkide kardeş sayısı ve birim alandaki tane verimini artırmaktadır (Singh et al. 1975). Avcı ve ark. (1987), değişik tohum iriliklerinin buğdayda verim artışı sağladığını, Khan et al. (2000), kuru şartlarda iri tohumların metrekaredeki bitki sayısı ve tane verimini artırdığını, Main and Nafziger (1994) iri tohumların çevresel stres şartlarından özellikle kurak şartlarda avantaj sağladığını, Akıncı ve Yıldırım (2007), küçük taneli tohumların çıkış oranın düşük olmasından birim alandaki bitki sayısı azalarak kalite özelliklerinden 1000 tane ve hektolitre ağırlığı değerlerinin yüksek olduğunu bildirmişlerdir.

Araştırmada farklı 1000 tane ağırlıklarına sahip dört ekmeklik buğday çeşidinde (Flamura85 ve Gelibolu iri, Kate A-1 orta iri ve Guadalupe küçük taneli) 4 farklı tohum iriliğinin $(2.8 \mathrm{~mm}$ üstü, 2.8-2.5 mm arası, 2.5-2.2 $\mathrm{mm}$ arası ve 2.2-2.0 $\mathrm{mm}$ arası) tane verimi, verim öğeleri ve bazı kalite değerleri üzerine etkisini belirlemek amacıyla yapılmıştır. Ayrıca bölgedeki bu çeşitler için en uygun tohum iriliklerinin belirlenmesi amaçlanmıştır.

\section{Materyal ve Yöntem}

Trakya Tarımsal Araştırma Enstitüsü deneme alanında 2007-2009 yetiştirme sezonlarında yürütülen bu araştırma 4 ekmeklik buğday çeşidi ana parsel (Flamura-85, Gelibolu, Kate A-1 ve Guadalupe), 4 farklı tohum irilikleri (2.8 $\mathrm{mm}$ üstü, 2.8-2.5 $\mathrm{mm}$ arası, 2.5-2.2 $\mathrm{mm}$ arası ve $2.2-2.0 \mathrm{~mm}$ arası) alt parsel olarak ele alınmıştır. Deneme, Tesadüf Bloklarında Bölünmüş Parseller Deneme Desenine göre dört tekrarlamalı olarak yürütülmüştür.

Ekim, $\mathrm{m}^{2}$ ye 500 adet tohum olacak şekilde $7 \mathrm{~m} \times 1 \mathrm{~m}=7 \mathrm{~m}^{2}$ parsellere özel ekim mibzeriyle yapılmıştır. Hasatta ise parseller $6 \mathrm{~m} \times 1 \mathrm{~m}=6 \mathrm{~m}^{2}$ alan üzerinden değerlendirilmiştir. Tane verimi için parseller özel hasat-harman makinesiyle (Hege) yapılmış, elde edilen ürün tartılarak parsel verimleri hesaplanmıştır. Metrekarede basak sayısı; hasat oncesi olgunlasma aşamasında $50 \mathrm{~cm} \times 50 \mathrm{~cm}$ 'lik çerçeve kullanılarak her parselin 3 farklı yerinde başakların sayımları yapılmıştır. Hasat sonrası 1000 tane ağırlığı, hektolitre ağırlığı ve protein oranı gibi kalite analizleri yapılmıştır. Örneklerde hektolitre ağırlığı ve bin tane ağırlığı Uluöz (1965)'e göre, protein oranı (azot oranı * 5.83) AOAC 992.23 metoduyla ve LECO FP 528 azot tayin cihazı ile belirlenmiştir (Anon., 2009).

\section{Bulgular ve Tartışma}

Yapılan varyans analiz sonucunda tane verimi, metrekarede başak sayısı, başakta tane sayısı, bin tane ağırlığı ve hektolitre ağırığı yönünden çeşitler arasındaki farklılık istatistiki olarak önemli bulunmuştur. Tohum iriliği, her iki yılda da tane verimi, 1000 tane ağırlığı ve hektolitre ağırlığını etkilerken, metrekarede başak sayısı ve başakta tane sayısını etkilememiştir.

\section{Tane Verimi (kg/da)}

Çizelge 1 incelendiğinde tane verimi yönünden; tohum irilikleri ve çeşit ortalamaları arasındaki farklılıklar istatistiki anlamda önemli; çeşit $x$ tohum iriliği interaksiyonu önemsiz bulunmuştur. Tane verimi yönünden yıllar arasında farklılık önemli olmuştur. Tohum iriliği her iki yılda da tane verimi üzerine etkili olmuştur. Tohum iriliklerine göre çeşitlerin 1.yıl tane verimleri $770.8-837.7 \mathrm{~kg} / \mathrm{da}$ arasında 
Table 1. 2007-2009 yılları farklı 1000 tane ağırlıklarına sahip dört ekmeklik buğday çeşidinin tane verimlerinin $(\mathrm{kg} / \mathrm{da})$ ortalama değerleri, interaksiyonları ve oluşturdukları gruplar

Table 1. Yield averages ( $\mathrm{kg} / \mathrm{da})$, interactions and LSD groups of 4 bread wheat varieties with different thousand kernel weights in 2007-2009

\begin{tabular}{lccc}
\hline & \multicolumn{1}{c}{ Yıllar } \\
\hline Tohum İrilikleri & $2007-2008$ & $2008-2009$ & $2007-2009$ \\
\hline 1) $2.8 \mathrm{~mm}$ üstü & $837.7 \mathrm{a}$ & $805.3 \mathrm{a}$ & $821.5 \mathrm{a}$ \\
2) $2.5-2.8 \mathrm{~mm}$ arası & $816.9 \mathrm{ab}$ & $798.3 \mathrm{ab}$ & $807.6 \mathrm{ab}$ \\
3) $2.2-2.5 \mathrm{~mm}$ arası & $808.1 \mathrm{~b}$ & $765.7 \mathrm{~b}$ & $786.9 \mathrm{~b}$ \\
4) $2.0-2.2 \mathrm{~mm}$ arası & $770.8 \mathrm{c}$ & $710.8 \mathrm{c}$ & - \\
\hline Ortalama & $808.4 \mathrm{a}$ & $770.0 \mathrm{~b}$ & 21.0 \\
EKÖF (P <0.05): & 25.7 & 34.1 & 5.34 \\
Irilik & 4.44 & 6.17 & \\
CV (\% $)$ & & &
\end{tabular}

EKÖF (P <0.05): Yıl: 22.4

\begin{tabular}{lcccccccc}
\hline & \multicolumn{7}{c}{ Çeşitler } \\
\hline Tohum İrilikleri & \multicolumn{2}{c}{ Flamura-85 } & \multicolumn{2}{c}{ Gelibolu } & \multicolumn{2}{c}{ Kate A-1 } & \multicolumn{2}{c}{ Guadalupe } \\
\hline & $2007-08$ & $2008-09$ & $2007-08$ & $2008-09$ & $2007-08$ & $2008-09$ & $2007-08$ & $2008-09$ \\
\hline 1) $2.8 \mathrm{~mm}$ üstü & 804.3 & 764.0 & 869.1 & 824.0 & 869.8 & 835.2 & 807.6 & 798.1 \\
2) $2.5-2.8 \mathrm{~mm}$ arası & 809.9 & 750.7 & 807.6 & 815.6 & 859.5 & 846.1 & 790.8 & 780.8 \\
3) $2.2-2.5 \mathrm{~mm}$ arası & 749.2 & 721.8 & 810.9 & 780.2 & 874.6 & 792.1 & 797.8 & 768.8 \\
4) $2.0-2.2 \mathrm{~mm}$ arası & 735.3 & 651.6 & 737.9 & 709.4 & 825.0 & 745.5 & 784.9 & 736.7 \\
\hline Ortalama & $774.7 \mathrm{~b}$ & $722.0 \mathrm{~b}$ & $806.4 \mathrm{~b}$ & $782.3 \mathrm{a}$ & $857.2 \mathrm{a}$ & $804.7 \mathrm{a}$ & $795.3 \mathrm{~b}$ & $771.1 \mathrm{ab}$
\end{tabular}

EKÖF (P <0.05): 2007-08; Çeşit: 44.9, 2008-09; Çeşit: 51.6

LSD ( $P<0.05):$ 2007-08; Variety:44.9, 2008-09; Variety:51.6

değişim göstermiştir. En yüksek tane verimi $837.7 \mathrm{~kg} / \mathrm{da}$ ile $2.8 \mathrm{~mm}$ üstü tohum iriliğinden elde edilirken en düşük tane verimi ise 770.0 $\mathrm{kg} / \mathrm{da}$ ile 2.2-2.0 $\mathrm{mm}$ arası tohum iriliğinden elde edilmiştir. İkinci yılda ise tane verimi 710.8$805.3 \mathrm{~kg} / \mathrm{da}$ arasında değişmiştir. En yüksek tane verimi $805.3 \mathrm{~kg} / \mathrm{da}$ ile $2.8 \mathrm{~mm}$ üstü tohum iriliğinden elde edilirken en düşük tane verimi ise $710.8 \mathrm{~kg} / \mathrm{da}$ ile $2.2-2.0 \mathrm{~mm}$ arası tohum iriliğinden elde edilmiştir. Her iki yılda da tohum iriliği ile tane verimi arasında paralel sonuçlar alınmıştır. Tohum iriliği düştüğünde tane verimide düşüş göstermiştir.

Tohum iriliği yüksek olan tohumların tane veriminin yüksek olması (Khan et al. 2000) metrekarede başak sayısı, 1000 tane ve hektolitre ağırlıklarının yüksek olmasından kaynaklanmıştır.

Çeşitlerin tane verim ortalamaları 1. yıl $774.7-857.2 \mathrm{~kg} / \mathrm{da}$ arasında, 2. yıl ise $722.0-$ $804.7 \mathrm{~kg} / \mathrm{da}$ arasında değişim götermiştir. Çeşitlerin 2.yıldaki tane veriminin 1. yıldan daha fazla olması metrekaredeki başak sayısının fazla olmasından kaynaklanmıştır. Çeşitlerin tane verimleri her iki yılda da $2.8 \mathrm{~mm}$ üstü tohum iriliğinde en yüksek olurken, 2.2-2.0 mm arası tohum iriliğinde ise en düşük olmuştur. Çeşitlerin tohum irilikleri arasındaki tane verim artışı 1000 tane ağırlığı yüksek olan Flamura85 ve Gelibolu çeşitlerinde fazla olurken, 1000 tane ağırlığı düşük olan Kate A-1 ve Guadalupe çeşitlerde ise daha düşük olmuştur. Çeşitler bazında en iri tohum ile en küçük tohum arasında tane verimi artışları; Gelibolu çeşidinde, birinci yıl \%17.8, ikinci yıl \%16.2, Flamura-85 çeşidinde, birinci yıl \%9.4, ikinci yıl $\% 17.2$, Kate A-1 çeşidinde, birinci yıl \%5.4, ikinci yıl \%12.0, Guadalape çeşidinde ise birinci yıl \%2.9, ikinci yıl \%8.3 olmuştur. 1000 tane ağırlığı yüksek olan çeşitlerde tohum irilikleri arasındaki tane verimleri arasındaki farklar fazla olurken tane ağırlığı küçük çeşitlerde artış daha az olmuştur. Çalışmamıza benzer olarak bazı araştırıcılar iri tohumların tane veriminin küçük tohumlardan daha fazla olduğunu bildirirken (Singh et al. 1975; Avcl ve ark. .1987; Spilde 1989; Ünver 1995; Khan et al. 2000; Barut 2003; Akıncı ve Yıldırım 2007; Karaman ve ark. 2014) bazı araştırıcılar ise tane iriliğinin tane verimi üzerine etkisinin olmadığını bildirmişlerdir (Taner ve ark. 2011).

\section{Metrekarede Başak Sayısı (adet)}

Tane iriliği her iki yılda da metrekarede başak sayısı üzerine etkili olmamıştır. Tohum iriliklerine göre 1. yıl metrekarede başak sayısı 404.3-414.3 adet $/ \mathrm{m}^{2}$ arasında değişmiştir. Metrekarede başak sayısı en fazla 414.3 adet $/ \mathrm{m}^{2}$ ile $2.8-2.5 \mathrm{~mm}$ arası tohum iriliğinden alınırken en düşük ise 404.3 adet ile $2.2-2.0 \mathrm{~mm}$ arası tohum iriliğinden alınmıştır. 2. yıl metrekarede başak sayısı 442.73-480.3 adet $/ \mathrm{m}^{2}$ arasında değişmiştir. Metrekarede 
Table 2. 2007-2009 yılları farklı 1000 tane ağırlıklarına sahip dört ekmeklik buğday çeşidinin metrekarede başak sayısı (adet) ortalama değerleri, interaksiyonları ve oluşturdukları gruplar

Table 2. Number of spikes per square meter, interactions and LSD groups of 4 bread wheat varieties with different thousand kernel weights in 2007-2009

\begin{tabular}{lccc}
\hline \multicolumn{3}{c}{ Yıllar } & \\
\hline Tohum İilikleri & $2007-2008$ & $2008-2009$ & $2007-2009$ \\
\hline 1) $2.8 \mathrm{~mm}$ üstü & 409.3 & 475.4 & $442.3 \mathrm{ab}$ \\
2) $2.5-2.8 \mathrm{~mm}$ arası & 414.3 & 480.3 & $447.3 \mathrm{a}$ \\
3) $2.2-2.5 \mathrm{~mm}$ arası & 407.5 & 469.1 & $438.3 \mathrm{ab}$ \\
4) $2.0-2.2 \mathrm{~mm}$ arası & 404.3 & 442.7 & $423.5 \mathrm{~b}$ \\
\hline Ortalama & $408.8 \mathrm{~b}$ & $466.9 \mathrm{a}$ & - \\
EKÖF (P <0.05): İilik & 19.53 & 34.60 & 19.53 \\
CV (\% ) & 6.66 & 10.34 & 8.95 \\
EKÖF (P <0.05): Yıl: 18.25 & & &
\end{tabular}

\begin{tabular}{|c|c|c|c|c|c|c|c|c|}
\hline & \multicolumn{8}{|c|}{ Çeşitler } \\
\hline \multirow{2}{*}{ Tohum İrilikleri } & \multicolumn{2}{|c|}{ Flamura-85 } & \multicolumn{2}{|l|}{ Gelibolu } & \multicolumn{2}{|l|}{ Kate A-1 } & \multicolumn{2}{|c|}{ Guadalupe } \\
\hline & $2007-08$ & 2008-09 & $2007-08$ & $2008-09$ & $2007-08$ & $2008-09$ & $2007-08$ & $2008-09$ \\
\hline 1) $2.8 \mathrm{~mm}$ üstü & $372 \mathrm{gh}$ & 455.0 & 412 def & 461.0 & 449 bcd & 550.8 & 404 efg & 434.8 \\
\hline 2) $2.5-2.8 \mathrm{~mm}$ arası & $378 \mathrm{fgh}$ & 439.0 & $372 \mathrm{gh}$ & 534.3 & $484 a b$ & 505.0 & $423 \mathrm{cde}$ & 442.8 \\
\hline 3) $2.2-2.5 \mathrm{~mm}$ arası & $355 \mathrm{~h}$ & 469.5 & $380 \mathrm{gh}$ & 475.5 & $494 \mathrm{a}$ & 507.5 & 401 efg & 424.0 \\
\hline 4) $2.0-2.2 \mathrm{~mm}$ arası & $382 \mathrm{fgh}$ & 470.0 & 401 efg & 432.3 & $460 \mathrm{ac}$ & 450.0 & $374 \mathrm{fgh}$ & 418.5 \\
\hline Ortalama & $371.8 \mathrm{~b}$ & $458.4 \mathrm{bc}$ & $391.3 \mathrm{~b}$ & $475.8 \mathrm{ab}$ & $471.8 \mathrm{a}$ & $503.3 \mathrm{a}$ & $400.5 \mathrm{~b}$ & $430.0 \mathrm{~cd}$ \\
\hline
\end{tabular}

EKÖF (P <0.05): 2007-08; Çeşit: 40.97, Çeşitxİirilik: 39.07, 2008-09; Çeşit: 37.56

LSD (P<0.05): 2007-08; Variety:40.97,VarietyxSize:39.07, 2008-09; Variety:37.56

Table 3. 2007-2009 yılları farklı 1000 tane ağırlıklarına sahip dört ekmeklik buğday çeşidinin başakta tane sayısı (adet) ortalama değerleri, interaksiyonları ve oluşturdukları gruplar

Table 3. Number of kernels per spike, interactions and LSD groups of 4 bread wheat varieties with different thousand kernel weights in 2007-2009

\begin{tabular}{lccc}
\hline & & Yllar & \\
\hline Tohum İrilikleri & $2007-2008$ & $2008-2009$ & $2007-2009$ \\
\hline 1) $2.8 \mathrm{~mm}$ üstü & 51.5 & 48.5 & 50.0 \\
2) $2.5-2.8 \mathrm{~mm}$ arası & 53.0 & 48.1 & 50.6 \\
3) $2.2-2.5 \mathrm{~mm}$ arası & 52.7 & 49.1 & 50.9 \\
4) $2.0-2.2 \mathrm{~mm}$ arası & 54.2 & 49.4 & 51.8 \\
\hline Ortalama & $52.9 \mathrm{a}$ & $48.8 \mathrm{~b}$ & - \\
EKÖF (P <0.05): İrilik & - & - & - \\
CV (\% ) & 7.95 & 8.38 & 8.16 \\
EKÖF (P <0.05): Yıl: 126 & & &
\end{tabular}

\begin{tabular}{lcccccccc}
\hline \multicolumn{1}{l}{ EKOF (P <0.05): YII: 1.26} \\
\hline & Flamura-85 & Gelibolu & \multicolumn{3}{c}{ Ceşitler } \\
\hline Tohum İrilikleri & $2007-08$ & $2008-09$ & $2007-08$ & $2008-09$ & $2007-08$ & $2008-09$ & $2007-08$ & $2008-09$ \\
\hline & 48.1 & 44.8 & 49.0 & 47.5 & 46.5 & 48.8 & 62.7 & 53.0 \\
\hline 1) $2.8 \mathrm{~mm}$ üstü & 53.7 & 44.3 & 49.4 & 46.0 & 48.0 & 49.0 & 61.1 & 53.0 \\
2) $2.5-2.8 \mathrm{~mm}$ arası & 53.5 & 46.5 & 50.5 & 48.3 & 49.6 & 53.3 & 61.1 & 48.3 \\
3) $2.2-2.5 \mathrm{~mm}$ arası & 49.7 & 45.5 & 48.1 & 47.5 & 49.6 & 51.8 & 65.7 & 52.8 \\
4) $2.0-2.2 \mathrm{~mm}$ arası & $51.2 \mathrm{~b}$ & $45.3 \mathrm{~b}$ & $49.2 \mathrm{~b}$ & $47.3 \mathrm{~b}$ & $48.4 \mathrm{~b}$ & $50.7 \mathrm{a}$ & $62.6 \mathrm{a}$ & $51.8 \mathrm{a}$ \\
\hline Ortalama & 51.9 & & &
\end{tabular}

Ortalama $\quad 51.2$ b $\quad 45.3$ b $\quad 49.2$ b $\quad 47.3$

LSD ( $P<0.05)$ : 2007-08; Variety:3.14, 2008-09; Variety:2.21

başak sayısı en fazla $480.3 \mathrm{adet} / \mathrm{m}^{2}$ ile 2.8-2.5 $\mathrm{mm}$ arası tohum iriliğinden alınırken en düşük ise 442.3 adet $/ \mathrm{m}^{2}$ ile $2.2-2.0 \mathrm{~mm}$ arası tohum iriliğinden alınmıştır.

Tohum iriliklerine göre metrekarede başak sayılarında 1. yıl fark olmazken 2. yıl ise farklılıklar olmuştur. 1. yıl tane veriminin yüksekliği başaktaki tane sayısı, 1000 tane ve hektolitre ağırlıklarının fazla olmasından kaynaklanmıştır. Çalışmamızda tohum iriliğinin metrekarede başak sayısını artırdığını fakat istatistiki olarak önemli olmadığı görülürken bazı araştırıcılar ise iri tohumların metrekarede başak sayısında önemli artışların olduğunu bildirmişlerdir (Spilde, 1989; Khan et al. 2000; Akıncı ve Yıldırım, 2007; Karaman ve ark. 2014). 


\section{Başakta Tane Sayısı (adet)}

Çizelge 3 incelendiğinde tohum iriliğinin her iki yılda da başakta tane sayısı üzerine etkisi olmadığı görülmektedir. 1. yıl başakta tane sayısı 51.5-54.2 adet, arasında değişmiştir. 2. yılda ise 48.1-49.4 adet arasında değişmiştir. 1.yıl başakta tane sayısının 2. yıldan fazla olmasının sebebi 1. yıl metrekaredeki başak sayısının 2. yıldan daha az olmasından kaynaklanmıştır. Kate A-1 çeşidi hariç diğer tüm buğday çeşitlerinde tohum iriliklerinde benzer şekilde 1. yıldaki başakta tane sayısı 2. yıldaki başakta tane sayısından fazla olduğu görülmektedir. Karaman ve ark. (2014), tohum iriliğinin başakta tane sayısını etkilemediği sonucunu bulmuştur.

\section{Bin Tane Ağırlığı (g)}

Tohum iriliklerinin çeşitlerin 1000 tane ğırlığı üzerine her iki yılda da olumlu etkisi olmuştur. 1 . yıl çeşitlerin tohum iriliklerine göre 1000 tane ağırlığı $37.0-37.9 \mathrm{~g}, 2$ yılda ise $34.2-36.1 \mathrm{~g}$ arasında değişmiştir. 1000 tane ağırlığı yönünden 1. yıl tohum irilikleri arasındaki farklar çok düşük olurken, 2. yıl bu değer daha yüksek olmuştur. Bundan dolayı çeşitlerin tohum irilikleri arasında da tane verimi yönünden önemli farkların olmasına neden olmuştur. Çalışmamıza benzer olarak tohum iriliğinin çeşitlerde 1000 tane ağırlığını etkilediğini bildirmiştir (Pavez Saa 1989; Akıncı ve Yıldırım 2007; Taner ve ark. 2011; Karaman ve ark. 2014).

\section{Hektolitre Ağırlığı (kg)}

Çizelge 5 incelendiğinde görüleceği gibi tohum iriliğinin her iki yılda da hektolitre ağırlığı üzerinde önemli etkileri olmuştur. Tohum iriliklerine göre çeşitlerin hektolitre ağırlıkları 1. yılda 81.3-81.9 kg arasında, 2 . yılda ise $79.0-79.9 \mathrm{~kg}$ arasında değişim göstermiştir. Her iki yılda da çeşitlerin tohum irilikleri arasındaki hektolitre ağırlıkları yönünden fazla farklar olmamıştır. Çeşitlerin tane irilikleri artıkça hektolitre ağırlıklarıda az da olsa artış göstermiştir. Akıncı ve Yıldırım (2007) ile Taner ve ark. (2011) çalışmamıza benzer şekilde tohum iriliğinin çeşitlerin hektolitre ağırığını etkilediğini sonucunu bulmuşlardır.

Tohum iriliği artıkça çeşitlerin tane verimi artmıştır. En yüksek tane verimi $2.8 \mathrm{~mm}$ üstü tohum iriliğinden alınırken, en düşük tane verimi ise $2.0-2.2 \mathrm{~mm}$ arası tohum iriliğinden alınmıştır. 1000 tane ağırlığı yüksek olan çeşitlerde tohum iriliği artıkça tane verimindeki artış oranı daha fazla olmuştur. Çeşitlerin tohum iriliklerine (1000 tane ağırlığı) göre elek numaraları belirlenip; sertifikalı tohum üretiminde Gelibolu ve Flamura-85 gibi iri taneli çeşitler $2.5 \mathrm{~mm}$ üstü, Kate A-1 gibi orta iri çeşit $2.2 \mathrm{~mm}$ üstü ve Guadalupe gibi küçük çeşit için $2.0 \mathrm{~mm}$ elek üstü tohumluklar kullanımalıdır.

Table 4. 2007-2009 yılları farklı 1000 tane ağırlıklarına sahip dört ekmeklik buğday çeşidinin bin tane ağırlığı (g) ortalama değerleri, interaksiyonları ve oluşturdukları gruplar

Table 4. Thousand kernel weights, interactions and LSD groups of 4 bread wheat varieties with different thousand kernel weights in 2007-2009

\begin{tabular}{|c|c|c|c|c|c|c|c|c|}
\hline \multirow{2}{*}{\multicolumn{2}{|c|}{ Tohum İrilikleri }} & & \multicolumn{6}{|c|}{ Yillar } \\
\hline & & \multicolumn{3}{|c|}{$2007-2008$} & \multicolumn{2}{|c|}{$2008-2009$} & \multicolumn{2}{|c|}{ 2007-2009 } \\
\hline \multicolumn{2}{|l|}{ 1) $2.8 \mathrm{~mm}$ üstü } & \multirow{2}{*}{\multicolumn{3}{|c|}{$\begin{array}{l}37.0 \mathrm{~b} \\
37.9 \mathrm{a}\end{array}$}} & \multicolumn{2}{|c|}{$36.1 \mathrm{a}$} & \multicolumn{2}{|c|}{$36.6 \mathrm{a}$} \\
\hline \multicolumn{2}{|l|}{ 2) $2.5-2.8 \mathrm{~mm}$ arası } & & & & \multicolumn{2}{|l|}{$35.2 \mathrm{~b}$} & \multicolumn{2}{|c|}{$36.6 \mathrm{a}$} \\
\hline \multicolumn{2}{|l|}{ 3) $2.2-2.5 \mathrm{~mm}$ arası } & \multicolumn{3}{|c|}{$37.1 \mathrm{~b}$} & \multicolumn{2}{|l|}{$35.5 a b$} & \multicolumn{2}{|c|}{$36.3 a b$} \\
\hline \multicolumn{2}{|l|}{ 4) $2.0-2.2 \mathrm{~mm}$ arası } & & \multicolumn{2}{|l|}{$37.8 \mathrm{a}$} & \multicolumn{2}{|l|}{$34.2 \mathrm{c}$} & \multicolumn{2}{|c|}{$36.0 \mathrm{~b}$} \\
\hline \multirow{3}{*}{\multicolumn{2}{|c|}{$\begin{array}{l}\text { Ortalama } \\
\text { EKÖF (P <0.05): İrilik } \\
\text { CV (\% ) } \\
\text { EKÖF (P <0.05): Yıl: } 1.03\end{array}$}} & & \multicolumn{2}{|l|}{$37.5 \mathrm{a}$} & \multicolumn{2}{|l|}{$35.3 \mathrm{~b}$} & \multicolumn{2}{|c|}{-} \\
\hline & & & \multirow{2}{*}{\multicolumn{2}{|c|}{$\begin{array}{l}0.22 \\
0.82\end{array}$}} & \multicolumn{2}{|l|}{0.84} & \multicolumn{2}{|c|}{0.43} \\
\hline & & & & & \multicolumn{2}{|l|}{3.32} & \multicolumn{2}{|c|}{2.35} \\
\hline & & & & & Çeşitler & & & \\
\hline \multirow[t]{2}{*}{ Tohum İrilikleri } & \multicolumn{2}{|c|}{ Flamura-85 } & \multicolumn{2}{|c|}{ Gelibolu } & \multirow{2}{*}{\multicolumn{2}{|c|}{\begin{tabular}{c}
\multicolumn{2}{c}{ Kate A-1 } \\
$2007-08 \quad 2008-09$
\end{tabular}}} & \multicolumn{2}{|c|}{ Guadalupe } \\
\hline & $2007-08$ & $2008-09$ & $2007-08$ & $2008-09$ & & $2008-09$ & $2007-08$ & $2008-09$ \\
\hline 1) $2.8 \mathrm{~mm}$ üstü & $42.4 \mathrm{bc}$ & 38.0 a-d & $38.7 \mathrm{f}$ & $38.5 a b c$ & $36.0 \mathrm{~h}$ & $34.4 \mathrm{e}$ & 30.9 I & 33.7 ef \\
\hline 2) $2.5-2.8 \mathrm{~mm}$ arası & $43.2 \mathrm{a}$ & $39.2 a b$ & $42.7 \mathrm{ab}$ & $37.6 \mathrm{bcd}$ & $36.1 \mathrm{~h}$ & 33.3 ef & $29.6 \mathrm{k}$ & $30.8 \mathrm{~h}$ \\
\hline 3) $2.2-2.5 \mathrm{~mm}$ arası & $40.3 \mathrm{e}$ & $37.2 \mathrm{~cd}$ & $40.4 \mathrm{e}$ & 39.5 a & $37.7 \mathrm{~g}$ & 33.8 ef & $30.2 \mathrm{j}$ & $31.6 \mathrm{gh}$ \\
\hline 4) $2.0-2.2 \mathrm{~mm}$ arası & $41.2 \mathrm{~d}$ & $36.7 \mathrm{~d}$ & $42.2 \mathrm{c}$ & $36.6 \mathrm{~d}$ & $37.5 \mathrm{~g}$ & $32.5 \mathrm{fg}$ & $30.3 \mathrm{j}$ & $31.0 \mathrm{gh}$ \\
\hline Ortalama & $41.7 \mathrm{a}$ & $37.8 \mathrm{a}$ & $41.0 \mathrm{~b}$ & $38.0 \mathrm{a}$ & $36.8 \mathrm{c}$ & $33.5 \mathrm{~b}$ & $30.2 \mathrm{~d}$ & $31.7 \mathrm{~b}$ \\
\hline
\end{tabular}


Table 5. 2007-2009 yılları farklı 1000 tane ağırlıklarına sahip dört ekmeklik buğday çeşidinin hektolitre ağırlığı (kg) ortalama değerleri, interaksiyonları ve oluşturdukları gruplar

Table 5. Test weights, interactions and LSD groups of 4 bread wheat varieties with different thousand kernel weights in 2007-2009

\begin{tabular}{lccc}
\hline & & Yıllar & \\
\hline Tohum Irilikleri & $2007-2008$ & $2008-2009$ & $80.8 \mathrm{a}$ \\
\hline 1) $2.8 \mathrm{~mm}$ üstü & $81.7 \mathrm{a}$ & $79.9 \mathrm{a}$ & $80.8 \mathrm{a}$ \\
2) $2.5-2.8 \mathrm{~mm}$ arası & $81.8 \mathrm{a}$ & $79.7 \mathrm{ab}$ & $80.4 \mathrm{~b}$ \\
$3) 2.2-2.5 \mathrm{~mm}$ arası & $81.3 \mathrm{~b}$ & $79.4 \mathrm{~b}$ & $80.4 \mathrm{~b}$ \\
4) $2.0-2.2 \mathrm{~mm}$ arası & $81.9 \mathrm{a}$ & $79.0 \mathrm{c}$ & - \\
\hline Ortalama & $81.7 \mathrm{a}$ & $79.5 \mathrm{~b}$ & 0.17 \\
\hline EKÖF $(\mathrm{P}<0.05)$ : İilik & 0.16 & 0.32 & 0.43 \\
CV (\% & 0.27 & 0.56 & \\
EKÖF $(\mathrm{P}<0.05):$ Yıl: 0.22 & & &
\end{tabular}

\begin{tabular}{|c|c|c|c|c|c|c|c|c|}
\hline \multirow{3}{*}{ Tohum İrilikleri } & \multicolumn{8}{|c|}{ Çeşitler } \\
\hline & \multicolumn{2}{|c|}{ Flamura-85 } & \multicolumn{2}{|c|}{ Gelibolu } & \multicolumn{2}{|c|}{ Kate A-1 } & \multicolumn{2}{|c|}{ Guadalupe } \\
\hline & $2007-08$ & $2008-09$ & $2007-08$ & 2008-09 & $2007-08$ & 2008-09 & $2007-08$ & 2008-09 \\
\hline 1) $2.8 \mathrm{~mm}$ üstü & $82.7 \mathrm{bcd}$ & $80.6 \mathrm{a}$ & $81.2 \mathrm{~g}$ & $79.7 \mathrm{~d}$ & $83.4 \mathrm{a}$ & $80.5 \mathrm{a}$ & $79.8 \mathrm{~h}$ & $78.8 \mathrm{e}$ \\
\hline 2) $2.5-2.8 \mathrm{~mm}$ arası & $82.4 \mathrm{de}$ & $80.1 \mathrm{a}-\mathrm{d}$ & $83.0 \mathrm{~b}$ & $80.4 \mathrm{ab}$ & $82.8 \mathrm{bc}$ & 80.7 a & 79.0 । & $77.7 \mathrm{f}$ \\
\hline 3) $2.2-2.5 \mathrm{~mm}$ arası & 82.2 ef & $80.2 \mathrm{a}-\mathrm{d}$ & $81.2 \mathrm{~g}$ & $79.9 \mathrm{bcd}$ & $82.0 \mathrm{f}$ & $80.4 \mathrm{abc}$ & $79.9 \mathrm{~h}$ & $77.4 \mathrm{f}$ \\
\hline 4) $2.0-2.2 \mathrm{~mm}$ arası & $82.6 \mathrm{~cd}$ & $79.8 \mathrm{~cd}$ & $82.8 \mathrm{bc}$ & $79.1 \mathrm{e}$ & $82.9 \mathrm{bc}$ & $79.8 \mathrm{bcd}$ & 79.3 । & $77.3 \mathrm{f}$ \\
\hline Ortalama & $82.5 \mathrm{~b}$ & $80.2 \mathrm{a}$ & $82.0 \mathrm{c}$ & $79.8 \mathrm{a}$ & $82,8 \mathrm{a}$ & $80.4 \mathrm{a}$ & $79.5 \mathrm{~d}$ & $77.8 \mathrm{~b}$ \\
\hline
\end{tabular}

EKÖF (P <0.05): 2007-08; Çeşit:0.14, Çeşitx İilik:0.314, 2008-09; Çeşit:0.66; Çeşitx İrilik: 0.64

LSD (P<0.05): 2007-08; Variety:0.14,VarietyxSize:0.314, 2008-09; Variety:0.66, VarietyxSize:0.64

\section{Sonuç}

Araştırma sonuçlarına göre, tohum iriliği artıkça çeşitlerin tane verimi artmıştır. Bölgemizde yüksek tane verimi elde etmek için, Gelibolu ve Flamura-85 çeşitlerinde $2.5 \mathrm{~mm}$ üstü, Kate A-1 çeşidinde $2.2 \mathrm{~mm}$ üstü ve Guadalupe çeşidinde ise $2.0 \mathrm{~mm}$ elek üstü tohumluklar kullanılmalıdır.

\section{Kaynaklar}

Akıncı C. ve Yıldırım M., 2007. Tohum İriliğinin Makarnalık Buğdayın Verim ve Kalitesi Üzerine Etkisi. TOVAG-TÜBiTAK Araştırma Raporu. 2007, Diyarbakır

Avcı M., Güler M., Pala M., Karaca M. Ve Eyüboğlu H., 1987. Yetiştirme Tekniği Paketi Öğelerinin Orta Anadolu Bölgesi Kurak Koşullarında Buğday Verimine Etkileri. Türkiye Tahıl Sempozyumu, 6- 9 Ekim 1987, Bursa

Barut A., 2003. Bazı Yulaf Çeşitlerinde Ekim Zamanı ve Tohum İriliğinin Verim ve Verim Ögelerine Etkisi (Doktora Tezi). Ankara Ün. Fen Bil. Ens., Ankara

Chastain T. G. and Wysocki K. J., 1995. Stand establishment responses of soft white winter wheat to seedbed residue and seed size. Crop Sci., 35: 214-218

Douglas C.L. and Wilkins D.E., 1992. Influence of Tillage and Seeds on Wheat Emergence and Development. Agronomy Abstracts, ASA, Medison, WI, p. 323
Harmanşah F. ve Tanin Y., 1987. Tigem Hububat Tohumluğu Üretim Teknikleri ve Sözleşmeli Tohumluk Üretiminin Genel Esasları Türkiye Tahıl Simpozyumu, 6- 9 Ekim 1987, Bursa, 19-28

Kara B. ve Akman Z., 2007. Farklı tane iriliği ve ekim derinliklerinin buğday (Triticum aestivum L.)'ın kök ve toprak üstü organlarının ilk gelişmesine etkisi. Akdeniz Üni. Ziraat Fak. Dergisi, 20(2): 193-202

Karaman M., Aktaş H., Kendal E., Erdemci İ. ve Tekdal S., 2014. Bazı Ekmeklik Buğday Çeşitlerinde Tohum İrilikleri ile Verim ve Kalite Parametreleri Arasındaki İlişkinin Değerlendirilmesi. Uluslararası Katılımlı Türkiye 5.Tohumculuk Kongresi ve Sektörel İş Forumu, 19-23 Ekim 2014,Diyarbakır/Türkiye, 358-362

Khan R.U., Rashid A., Khan A. and Khan N.A., 2000. Yield component and seed yield of wheat as affected by seed size under the rain-fed condition of dera ismail khan. Pakistan Journal of Biological Sciences, 3(12): 19961997

Main M.A.R. and Nafziger E.D., 1994. Seed size and water potantial effects on germination and seedling growth of winter wheat. Crop Sci., 36: $169-171$

Mian A.R. and Nafzigier E.D., 1992. Seed Size Effects on Emergence, Head Number, Grain Yield of Winter Wheat. J. Prod. Agric., 5: 265268 
Kahraman ve Avcı "Bazı Ekmeklik Buğday Çesitlerinde Farklı Tohum İriliklerinin Tane Verimi, Verim Öğeleri ile Kalite Üzerine Etkisi"

Pavez Saa D., 1989. Effect of Seed Size and Sowing rate Wheat on Plant Development and Some Yield Components. Simente, 59(1-2): 21-29

Ries S.K. and Everson E.H., 1970. Protein content and seed size relationships with seedling vigor of wheat cultivars. Agronomy J., 65: 884-886

Singh A.K., Tripathi I.D. abd Chowdhury R.K., 1975. Effect of seed size on seedling growth and mature plant charactes in barley (Hordeum vulgare L.). Field Crop Abst., 29(10): 7661

Spilde L.A., 1989. Influence of seed size and test weight on several agronomic traits of barley and hard red spring Wheat. J. Prod. Agric., 2: 169-172
Sönmez F., 2000. Tohum iriliği ve azotun arpanın ilk gelişme devresinde kök ve toprak üstü organlara etkisi. Turkish J. Agric. For., 24: 669-675

Taner S., Çeri S., Kaya Y., Partigöç F., Ayrancı R., Özer E. ve Aydoğan S., 2011. Buğdayda tohum iriliğinin tane verimi bitki boyu ve bazı kalite unsurlarına etkisi. Tarla Bitkileri Merkez Araştırma Enstitüsü Dergisi, 20(2): 10-16

Uluöz M., 1965. Buğday un ve ekmek analiz metotları. Ege Ü. Z. F. Yayınları Yayın No: 57, İzmir

Ünver S., 1995. Buğdayda Tohum İriliğinin Verim ve Verim Öğeleri Üzerine Etkisi. Tarla Bitkileri Merkez Arş. Ens. Yayın No: 1, TARM Matbaası, Ankara 